\title{
Wybrane aspekty atrakcyjności gospodarczej i rozwoju przedsiębiorczości w miastach powiatowych subregionu siedleckiego w latach 2010-2019
}

\section{Agata Kucharska, Dariusz Piwowarczyk}

\section{STRESZCZENIE}

W artykule przeanalizowano wybrane elementy atrakcyjności gospodarczej miast powiatowych subregionu siedleckiego, rozumianego jako podregion statystyczny NUTS 3 siedlecki, położonego we wschodniej części województwa mazowieckiego. W ramach analizy scharakteryzowano najważniejsze uwarunkowania rozwoju gospodarczego tych miast, z uwzględnieniem powiązań komunikacyjnych i wyznaczonych terenów inwestycyjnych, a także najważniejsze aspekty działalności gospodarczej w przedmiotowych miastach, w tym największe przedsiębiorstwa oraz główne specjalizacje gospodarcze. Przeanalizowane zostały wybrane procesy rozwojowe w zakresie przedsiębiorczości w latach 20102019, a także wysokość funduszy unijnych pozyskanych przez beneficjentów z tych miast na projekty na rzecz poprawy konkurencyjności przedsiębiorstw.

Słowa kluczowe: subregion siedlecki, miasta powiatowe, atrakcyjność gospodarcza, rozwój przedsiębiorczości, dofinansowanie UE.

\section{Wstęp}

Na atrakcyjność gospodarczą miast składa się wiele uwarunkowań, które wpływają na ich zdolność do przyciagania działalności gospodarczej. Duże znaczenie mają: wielkość i ranga ośrodków, położenie w sieci osadniczej, powiązania transportowe, funkcje i specjalizacje gospodarcze. Tworzą one unikatowy dla każdego miasta zespół cech, warunkujących jego rozwój. W niniejszym artykule scharakteryzowano wybrane aspekty atrakcyjności gospodarczej niżej wymienionych miast oraz przebadano zachodzace w nich wybrane procesy rozwojowe w zakresie przedsiębiorczości. Przeanalizowano również wysokość funduszy unijnych pozyskanych przez beneficjentów z tych miast na projekty na rzecz poprawy konkurencyjności przedsiębiorstw.

Analizy dotyczyły miast powiatowych, które wyróżniają się wielkością i ranga w systemie osadniczym subregionu siedleckiego ${ }^{1}$, a także znaczeniem społeczno-gospodarczym. Są to:

\footnotetext{
${ }^{1}$ Obszar tożsamy z zasięgiem terytorialnym podregionu siedleckiego (jednostka statystyczna NUTS 3), obejmujący powiaty: garwoliński, łosicki, siedlecki, sokołowski, węgrowski oraz miasto Siedlce (na prawach powiatu).
} 
- Siedlce (77,9 tys. mieszkańców) - miasto na prawach powiatu rangi subregionalnej, skupiające szereg funkcji ponadlokalnych; ośrodek jest znaczącym węzłem komunikacyjnym w krajowym i międzynarodowym systemie transportowym, w mieście funkcjonuje ponadlokalny rynek pracy i koncentruje się wiele usług wyższego rzędu, w tym usługi publiczne z zakresu wojewódzkiej administracji rządowej i samorządowej oraz szkolnictwa wyższego; miasto pełni rolę bieguna wzrostu, oddziałującego na rozwój społeczno-gospodarczy całego subregionu,

- Sokołów Podlaski, Garwolin, Węgrów, Łosice (odpowiednio: 18,9 tys., 17,5 tys., 12,6 tys., 7,0 tys. mieszkańców) - ośrodki powiatowe o znaczeniu lokalnym w zakresie usług i rynku pracy, które aktywizują obszary wiejskie znajdujące się w ich otoczeniu.

Analizowane miasta powiatowe położone są w zasięgu ponadlokalnych korytarzy transportowych, przebiegających w obszarze województwa mazowieckiego, stanowiących pasma najwyższej aktywności społeczno-gospodarczej regionu (ryc. 1). W Siedlcach i Węgrowie od wielu lat na preferencyjnych warunkach funkcjonują obszary przemysłowe, objęte zasięgiem specjalnej strefy ekonomicznej (do 2026 r.).

Wyboru uwarunkowań atrakcyjności gospodarczej dokonano na podstawie analizy danych zastanych, w szczególności dokumentów strategicznych i planistycznych analizowanych miast, a także analiz przeprowadzonych przez Mazowieckie Biuro Planowania Regionalnego. Z uwagi na dopuszczalną objętość artykułu skoncentrowano się na wybranych uwarunkowaniach działalności gospodarczej (przemysłowej i usługowej), z pominięciem lokalnych uwarunkowań przyrodniczych, w tym związanych z działalnością rolniczą.

Przedmiotowa analiza obejmuje lata 2010-2019. Wybór początku badania związany jest z rozpoczęciem dystrybucji środków z Unii Europejskiej (UE) w perspektywie finansowej 2007-2013 (środki te były wypłacane od 2010 r.), a końca - z dostępnością danych dotyczących zrealizowanych projektów w perspektywie finansowej 2014-2020 (w trakcie pisania niniejszego artykułu).

\section{Wybrane uwarunkowania rozwoju gospodarczego}

Przeanalizowane zostały wybrane uwarunkowania rozwoju gospodarczego w miastach powiatowych subregionu siedleckiego, tj. wielkość i ranga ośrodków, położenie w sieci osadniczej, powiązania transportowe, funkcje i specjalizacje gospodarcze, pokrycie miejscowymi planami zagospodarowania przestrzennego oraz tereny inwestycyjne. Sa to uwarunkowania, do których w dużej mierze odnosiły się dokumenty strategiczne i planistyczne przedmiotowych miast. Najbardziej atrakcyjnym miastem do lokalizacji inwestycji w subregionie są Siedlce. Miasto jest największym ośrodkiem osadniczym wschodniej części województwa mazowieckiego i trzecim pod względem wielkości we wschodniej części kraju. Jego niekwestionowanym atutem jest położenie w międzynarodowym korytarzu transportowym KII (Berlin - Warszawa - Mińsk - Moskwa - Niżny Nowogród), obejmującym magistralną linię kolejową nr 2 (E-20), drogę krajową nr 2 oraz projektowaną autostradę A2. 


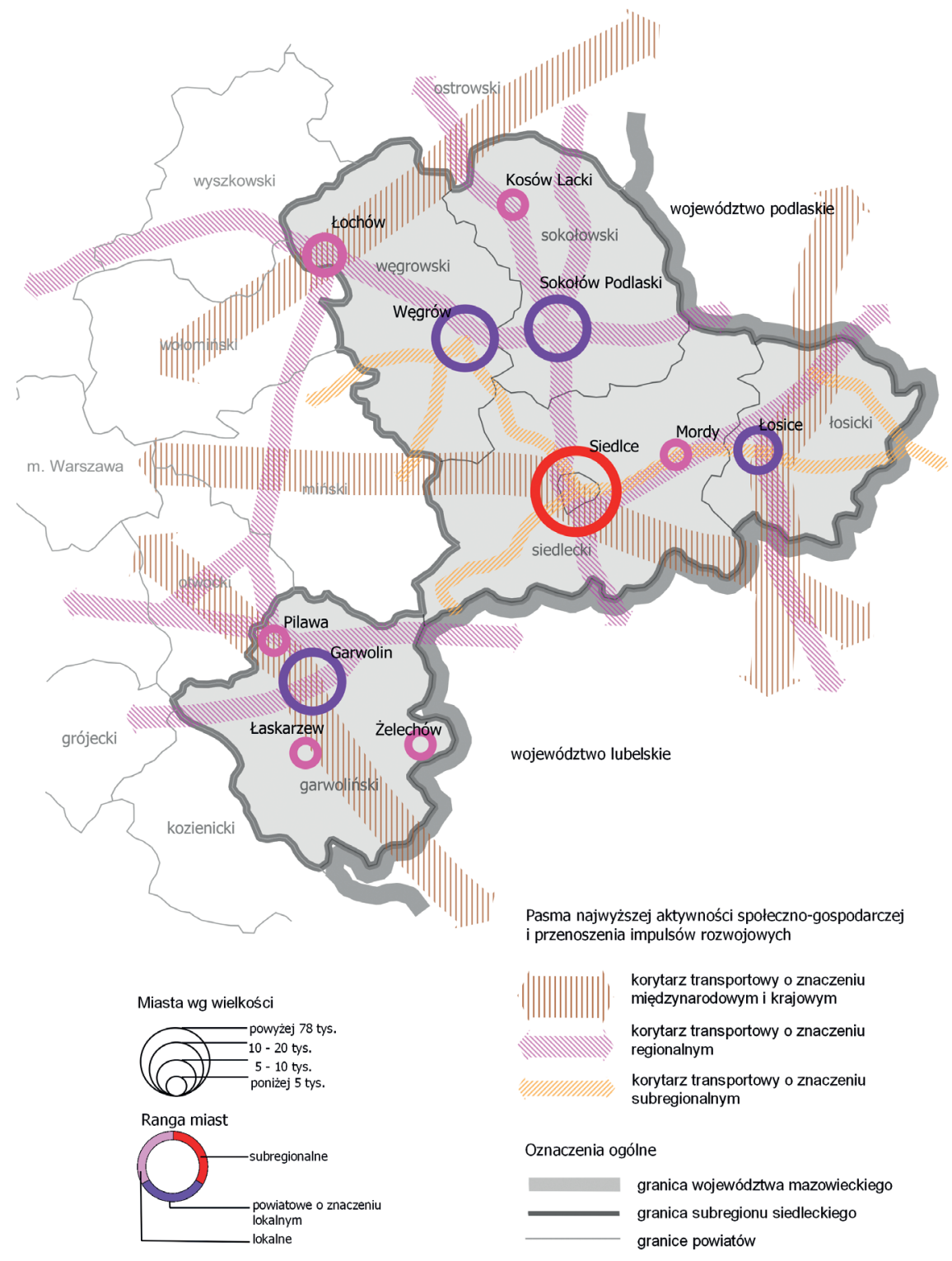

Ryc. 1. Sieć miejska subregionu siedleckiego

Źródło: opracowanie MBPR na podstawie Planu zagospodarowania przestrzennego województwa mazowieckiego 
Dużym walorem lokalizacyjnym Siedlec jest względnie nieduża odległość od stolicy kraju (ok. 90 km) oraz od przejścia granicznego z Białorusią w Terespolu (ok. 100 km). Atrakcyjna dla inwestorów jest duża dostępność siły roboczej (57\% ludności w wieku produkcyjnym w ogólnej liczbie ludności w 2019 r.) oraz jej wysoka jakość. Czynnikiem sprzyjającym lokalizacji inwestycji gospodarczych jest także dobrze rozwinięta infrastruktura techniczna, w tym dwustronne zasilanie miasta w energię elektryczną i gaz ziemny z systemów krajowych oraz lokalna elektrociepłownia, zapewniające wysoki poziom bezpieczeństwa energetycznego. W Siedlcach znajdują się uzbrojone i mające dobrą dostępność transportową duże kompleksy produkcyjno-usługowe i składowo-magazynowe, tj. Północna i Południowa Dzielnica Przemysłowa (odpowiednio: 125 ha i 350 ha) [Studium uwarunkowań i kierunków zagospodarowania przestrzennego miasta Siedlce 2013].

Ze względu na lokalizację wielu usług wyższego rzędu oraz instytucji otoczenia biznesu Siedlce pełnią funkcję subregionalnego centrum zarządzania rozwojem społeczno-gospodarczym. Przedsiębiorcom sprzyja dobrze rozwinięty system usług bankowych i ubezpieczeniowych. Duże znaczenie dla podmiotów gospodarczych ma także możliwość współpracy z Uniwersytetem Przyrodniczo-Humanistycznym, jedyną uczelnia publiczną w subregionie siedleckim. Zaplecze naukowo-badawcze uczelni, współpracującej z lokalną gospodarka, stwarza bardzo dobre warunki do lokalizacji przedsiębiorstw, wykorzystujących badania naukowe w swojej działalności, w szczególności w odniesieniu do podmiotów sektora rolno-spożywczego.

W Siedlcach prowadzona jest polityka, mająca na celu m.in. trwały i stabilny rozwój nowoczesnej gospodarki [Strategia rozwoju miasta Siedlce do 2025 r. 2015]. Aktywność władz miasta w pozyskiwaniu inwestorów przejawia się m.in. znacznym pokryciem Siedlec, w tym ww. terenów produkcyjno-usługowych i składowo-magazynowych, miejscowymi planami zagospodarowania przestrzennego (ponad 57\%). Władze miasta prowadza współpracę z przedsiębiorcami oraz instytucjami otoczenia biznesu, m.in. z powołana przez Prezydenta Miasta Siedlecką Radą Biznesu oraz z Europejskim Centrum Biznesu - firmą organizująca spotkania o charakterze polityczno-biznesowo-gospodarczym, z która miasto wspólnie w latach 2017-2019 organizowało Ogólnopolskie Szczyty Gospodarcze, stając się gospodarzem wydarzeń. Ponadto miasto angażuje się w projekty na rzecz poprawy jakości obsługi inwestora, wdrażając jednolite standardy obsługi, określone dla wszystkich samorządów lokalnych województwa mazowieckiego, a także w zakresie podnoszenia kwalifikacji uczniów do przyszłego zatrudnienia, m.in. poprzez organizację staży i praktyk uczniów szkół zawodowych w lokalnych firmach i instytucjach.

Pozostałe miasta powiatowe charakteryzują się podobnymi walorami lokalizacyjnymi. Lokalizacja Garwolina, przy drodze ekspresowej S17 (Warszawa - Hrebenne - granica państwa) i w pobliżu linii kolejowej nr 7 (Warszawa Wschodnia Osobowa - Dorohusk), stwarza duże możliwości rozwoju, gdyż zapewnia bezpośrednie połączenia miasta z Warszawą i Lublinem. W zakresie dostępności transportowej duże atuty mają Łosice, przez które przebiega droga krajowa nr 19 - planowana droga ekspresowa S19 (element korytarza Via Carpatia), zapewniająca połączenia z Białymstokiem i Lublinem. Miasto zlokalizowane jest zaledwie 
$70 \mathrm{~km}$ od przejść granicznych z Białorusią w Terespolu i Kukurykach. Sokołów Podlaski i Węgrów także charakteryzują się dość dobra dostępnością transportową. Przez obydwa ww. miasta przebiega droga krajowa nr 62, zapewniająca połączenia z województwami kujawsko-pomorskim i podlaskim. Ponadto przez Sokołów Podlaski przebiega droga krajowa nr 63, zapewniająca dobre połączenia z województwami: podlaskim i warmińsko-mazurskim oraz (przez Siedlce) z lubelskim [Plan zagospodarowania przestrzennego województwa mazowieckiego 2018]. Analizowane ośrodki położone są w odległości 70-130 km od Warszawy, a najlepsza jakość połączeń komunikacyjnych ze stolicą ma Garwolin.

Atutem lokalizacji inwestycji gospodarczych w miastach powiatowych jest duża dostępność siły roboczej (56-59\% ludności w wieku produkcyjnym w ogólnej liczbie ludności w 2019 r.), a także rozwinięte usługi okołobiznesowe (placówki bankowe i ubezpieczeniowe) i infrastruktura techniczna. Ośrodki miejskie zasilane są w energię elektryczną i gaz ziemny z systemów krajowych. Dodatkowym źródłem energii w Sokołowie Podlaskim jest lokalna ciepłownia, a w Węgrowie elektrownia wodna.

Władze lokalne wychodzą naprzeciw potrzebom inwestorów, starając się stworzyć jak najbardziej korzystne warunki do rozwoju przedsiębiorczości. Zgodnie z zapisami lokalnych strategii rozwoju, miasta dążą do tworzenia dobrego klimatu inwestycyjnego, w celu przyciągnięcia inwestorów zewnętrznych i rozwoju lokalnych firm, będących podstawą i zarazem największą szansą stabilnego wzrostu gospodarczego tych ośrodków. Wyraża się to m.in. stopniem pokrycia terenów miejscowymi planami zagospodarowania przestrzennego, które gwarantują przewidywalność w zagospodarowywaniu terenów i ułatwiaja przeprowadzanie procedur wydawania pozwoleń na budowę. Największe pokrycie miejscowymi planami odnotowano w Łosicach (100\%) oraz w Garwolinie (45,7\%). W Sokołowie Podlaskim i Węgrowie pokrycie planistyczne nie przekracza 6\%. Aktywność ośrodków miejskich w tym zakresie przejawia się również m.in. oferowaniem uzbrojonych terenów inwestycyjnych o charakterze produkcyjno-usługowo-technicznym. W granicach administracyjnych Garwolina znajduja się tereny inwestycyjne o łącznej powierzchni ok. 108 ha. Na terenach przyległych do obwodnicy wyznaczono Garwolińską Strefę Aktywności Gospodarczej o powierzchni ok. 60 ha [Strategia rozwoju miasta Garwolina... 2016]. Również Sokołów Podlaski dysponuje terenami o dużej koncentracji zakładów przemysłowych i przetwórczych. Przy drodze krajowej nr 62, na terenach po dawnej cukrowni „Elżbietów” miasto przygotowało Park Przemysłowy Sokołów Podlaski, w którym znajdują się powierzchnie o charakterze produkcyjno-magazynowo-biurowym [Gminny program rewitalizacji miasta Sokołów Podlaski... 2017]. W Węgrowie i Łosicach tereny produkcyjno-usługowe sa rozdrobnione i rozproszone, ale w pierwszym z ww. miast obszar 29,3 ha objęty jest wsparciem w ramach Tarnobrzeskiej Specjalnej Strefy Ekonomicznej EURO-PARK WISŁOSAN [https:/ / www.wegrow.com.pl]. 


\section{Działalność gospodarcza}

W 2019 r. w miastach subregionu siedleckiego zarejestrowano 15,2 tys. podmiotów gospodarczych, które stanowią ok. $44 \%$ przedsiębiorstw omawianego subregionu. Najwięcej przedsiębiorstw zarejestrowanych jest w Siedlcach - 8,7 tys. W pozostałych ośrodkach miejskich funkcjonuje ich znacznie mniej, tj. w Garwolinie i Sokołowie Podlaskim odpowiednio: 2,1 i 2,0 tys., a w Węgrowie i Łosicach odpowiednio: 1,5 tys. i 0,9 tys. firm. Przeważająca większość podmiotów gospodarczych (95,3\%), funkcjonujących w analizowanych miastach, to mikroprzedsiębiorstwa zatrudniające do 9 osób. Firmy małe (10-49 zatrudnionych osób) stanowią 3,6\% ogółu podmiotów. Najwięcej mikro i małych przedsiębiorstw ma swoje siedziby w Siedlcach, odpowiednio: 8,4 tys. i 280. Dużo mniejszą grupę stanowią firmy średniej wielkości (50 do 249 pracujących osób) - 138 przedsiębiorstw $(0,9 \%$ ), z czego 80 zarejestrowanych jest w Siedlcach. Firm dużych (powyżej 250 pracowników), w tym zatrudniających 1000 i więcej pracujących jest tylko 20, co stanowi 0,1\% wszystkich podmiotów w analizowanych miastach. Duże przedsiębiorstwa zlokalizowane są w większości w największych ośrodkach subregionu, tj. w Siedlcach (9 dużych, w tym 2 zatrudniające 1000 i więcej pracujących), w Sokołowie Podlaskim (5 dużych, w tym 1 zatrudniające przynajmniej 1000 pracujących) oraz w Garwolinie (4 duże, w tym 1 zatrudniające przynajmniej 1000 pracujących). W $2019 \mathrm{r}$. $\mathrm{w}$ Siedlcach funkcjonowało 26 przedsiębiorstw z kapitałem zagranicznym, tj. ponad połowa z 49, zarejestrowanych w całym subregionie siedleckim.

Wiele znaczących firm skorzystało z preferencyjnych warunków, stworzonych w analizowanych miastach powiatowych, wybierając na miejsce lokalizacji swoich inwestycji tereny znajdujące się w zasięgu stref aktywności gospodarczej (ryc. 2).

O dobrym poziomie rozwoju gospodarczego miast powiatowych subregionu siedleckiego świadczy rozwinięty sektor usługowy, zwłaszcza usług wyższego rzędu (sekcja J-R określona w Rozporządzeniu Rady Ministrów z dnia 24 grudnia 2007 r. w sprawie Polskiej Klasyfikacji Działalności - PKD 2007). W 2019 r. w strukturze branżowej podmiotów gospodarczych w tych ośrodkach (ryc. 3) dominowały przedsiębiorstwa prowadzące działalność usługowa, z których ponad połowa związana była z usługami wyższego rzędu świadczonymi przez kadrę o wysokich kwalifikacjach. Ponadto, w strukturze uwage zwracają znaczące udziały przedsiębiorstw prowadzących działalność związaną z przemysłem i przetwórstwem przemysłowym w Węgrowie (9,9\%) i Garwolinie (8,9\%) oraz firm związanych z transportem i gospodarką magazynowa w: Łosicach (11,8\%), Siedlcach $(8,4 \%)$ i w Sokołowie Podlaskim (8\%). 


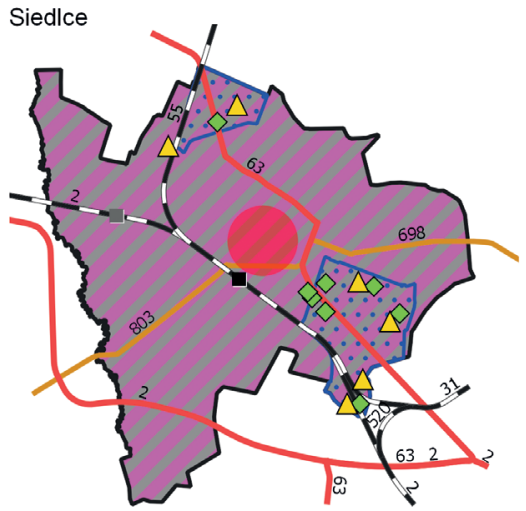

Sokołów Podlaski

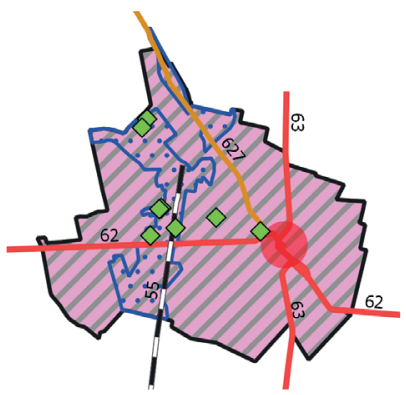

Węgrów

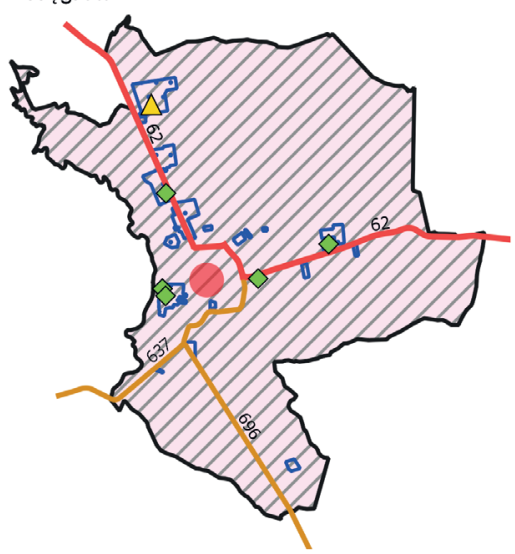

Garwolin

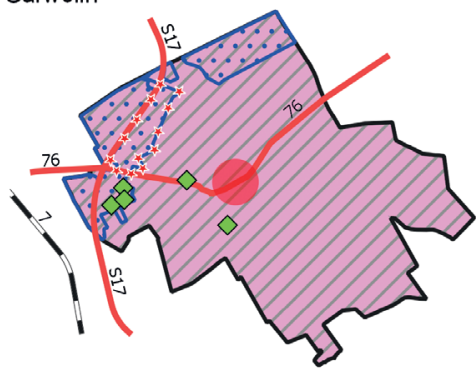

Udział podmiotów sektora usługowego w ogólnej liczbie podmiotów gospodarczych [\%]

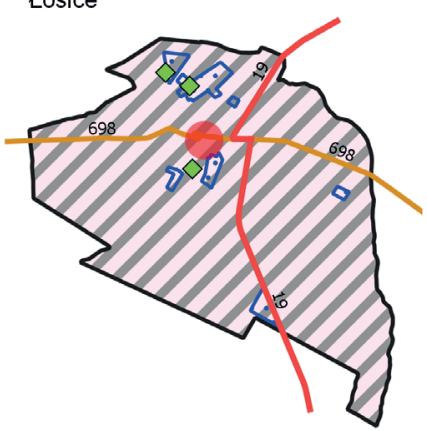

Obszary aktywności gospodarczej

miejsca koncentracji usług ponadlokalnych

... tereny produkcyjno-usługowe i składowo-magazynowe

$\diamond$ wybrane znaczące zakłady przemyslowe

$\triangle$ Specjalne Strefy Ekonomiczne (SSE)

*** Garwolińska Strefa Aktywności Gospodarczej

Podmioty gospodarcze wpisane do rejestru REGON w 2019 r.

$887-1500$

$1501-2107$

8735
$79,3-80,4$

$80,5-81,5$

$81,6-82,6$

2 drogi krajowe

698 drogi wojewódzkie

31 linie kolejowe

- stacje kolejowe

- przystanki kolejowe

- granice miast

Ryc. 2. Obszary aktywności gospodarczej w miastach powiatowych subregionu siedleckiego

Źródło: opracowanie MBPR na podstawie studiów uwarunkowań i kierunków zagospodarowania gmin, https://www.google.pl/maps oraz Banku Danych Lokalnych (BDL) 


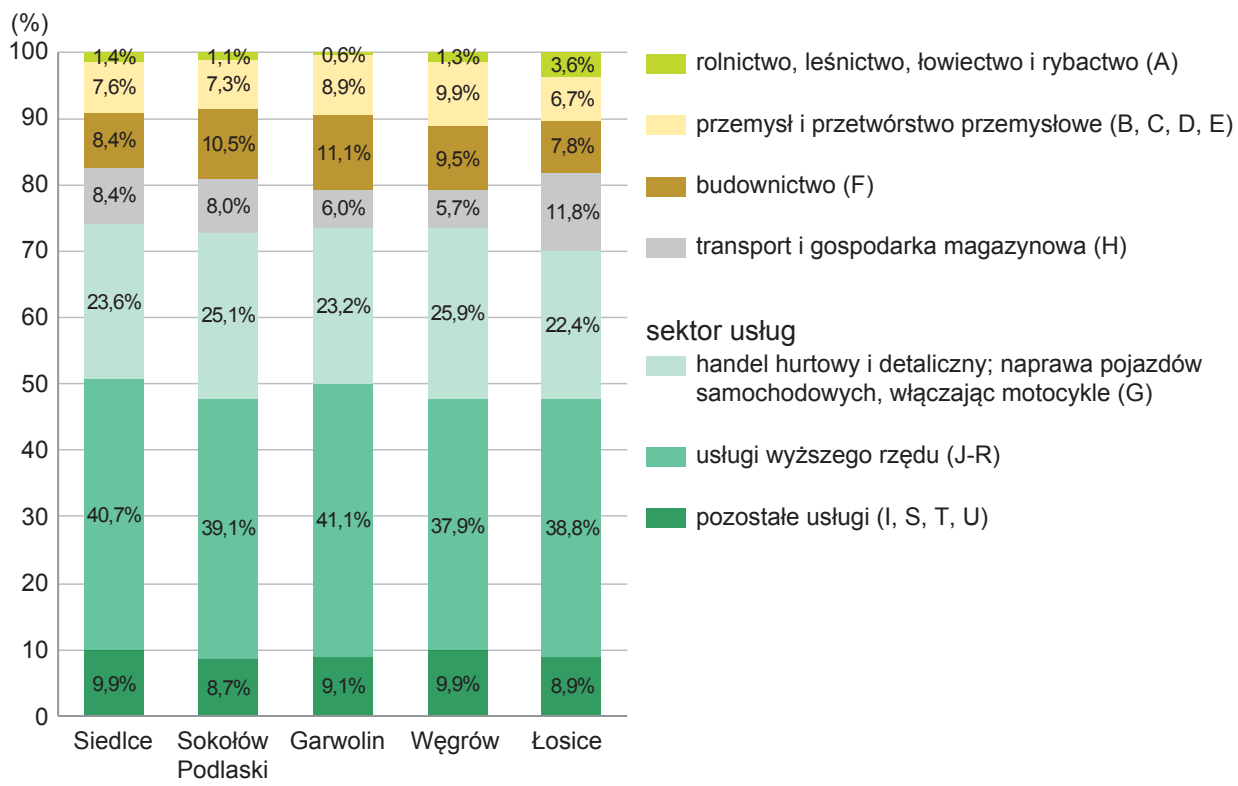

Ryc. 3. Struktura podmiotów gospodarczych w miastach powiatowych subregionu siedleckiego wg grup sekcji PKD 2007 w 2019 r.

Źródło: opracowanie MBPR na podstawie BDL

W Siedlcach od kilkudziesięciu lat szczególnie dobrze rozwija się przemysł rolno-spożywczy, metalowy i maszynowy. Do najważniejszych zakładów przemysłowych zalicza się m.in.: Stadler Polska sp. z o.o. (producent pojazdów szynowych), Mostostal Siedlce sp. z o.o. sp. k. (przedsiębiorstwo branży budowlanej, produkcyjnej), Altrad Mostostal sp. z o.o. (producent rusztowań budowlanych), Siedleckie Zakłady Drobiarskie „Drosed” S.A. (jeden z największych w Polsce producentów drobiu i jego przetworów), Real S.A. (producent mrożonych owoców i warzyw), a także PSI Spółdzielczy Producent Sprężyn, Carfi Polska (producent wyrobów z tworzyw sztucznych) i Fenes S.A. (producent narzędzi skrawających) [Strategia rozwoju miasta Siedlce... 2015]. Przedsiębiorstwa z Siedlec konkurują na krajowych rynkach, czego dowodem jest 6 zarejestrowanych w mieście firm, które znalazły się na publikowanej co roku przez czasopismo „Rzeczpospolita” Liście 2000 największych - pod względem wygenerowanych przychodów - przedsiębiorstw w kraju (tabela 1). Na ww. liście znajdują się także 2 zakłady z Garwolina i 1 z Sokołowa Podlaskiego [Lista 2000, 2020].

Sokołów Podlaski ma dobrze rozwinięte przetwórstwo rolno-spożywcze w branży mięsnej i mleczarskiej [Strategia rozwoju miasta Sokołów Podlaski 2002]. Największym przedsiębiorstwem działającym w Sokołowie Podlaskim jest Sokołów S.A. (jeden z największych w Polsce producentów wyrobów mięsnych). Do wiodących podmiotów należą również m.in.: Zakład Mleczarski Sokołów sp. z o.o. (producent wyrobów mlecznych), PHU Topaz (duża sieć handlowa), Sokołów-Logistyka sp. z o.o. (usługi transportowe), Spółka StalFa 
(producent konstrukcji stalowych), Jurex (zaopatrzenie rolnictwa, materiały budowlane) oraz Sawhal (technika grzewcza i sanitarna). W Garwolinie dominują małe i średnie przedsiębiorstwa, głównie z branży chemicznej, spożywczej, odzieżowej, maszynowej, meblarskiej, elektronicznej i rzemiosła skórzanego. Największą firmą pod względem zatrudnienia jest Avon Operations Polska sp. z o.o. (producent kosmetyków). Znaczącymi przedsiębiorstwami działającymi w branży chemicznej są również Erca Poland sp. z o.o. (producent komponentów chemicznych) i Berry Plastiape sp. z o.o. (producent tworzyw sztucznych). Wśród podmiotów gospodarczych innych branż wymienić należy m.in. Grazmat sp. z o.o. sp. k. (skup, sprzedaż i transport trzody chlewnej) i OCHNIK (producent odzieży skórzanej) [https://www.paih.gov.pl... 2012]. W gospodarce Węgrowa dominuje przetwórstwo rolno-spożywcze oraz produkcja materiałów budowlanych, mebli i części do maszyn. Do najważniejszych przedsiębiorstw produkcyjnych w Węgrowie zalicza się m.in.: Addit sp. z o.o. (producent elementów blaszanych), Hochland Polska sp. z o.o. (producent wyrobów mlecznych), Meblomaster sp. j., Filipek sp. z o.o. i Meblocross (producenci mebli drewnianych). Chluba miasta jest znany w kraju i za granica zakład ludwisarski rodziny Kruszewskich, produkujacy dzwony kościelne, okolicznościowe i pamiątkowe [Strategia rozwoju miasta Węgrowa... 2015]. Łosice mają istotny potencjał w zakresie działalności transportowej, ze względu na jeden z najniższych w kraju podatek od tego typu usług. Przedsiębiorcy z Łosic i okolic uznawani są za krajowych liderów w produkcji grzybów jadalnych. Do ważniejszych przedsiębiorstw w Łosicach należą m.in. Wokas S.A. (producent okrywy torfowej do uprawy pieczarek), Zakłady Mleczarskie „Laktopol-A” (producent wyrobów mlecznych) i Perun (producent sprzętu spawalniczego i gazowego) [Strategia rozwoju miasta i gminy Łosice... 2015].

Tabela 1. Zestawienie przedsiębiorstw z subregionu siedleckiego, które znalazły się na Liście 2000 „Rzeczpospolitej” (stan z 2019 r.)

\begin{tabular}{|c|c|l|l|}
\hline Lp. & $\begin{array}{c}\text { Pozycja na Liście 2000 } \\
\text { w } 2019\end{array}$ & \multicolumn{1}{|c|}{ Nazwa przedsiębiorstwa } & \multicolumn{1}{|c|}{ Lokalizacja } \\
\hline 1. & 91 & Grupa Sokołów S.A. & Sokołów Podlaski \\
\hline 2. & 251 & Stadler Polska sp. z o.o. & Siedlce \\
\hline 3. & 286 & Drosed S.A. GK & Siedlce \\
\hline 4. & 315 & Avon Operations Polska sp. z o.o. & Garwolin \\
\hline 5. & 889 & Carsed sp. z o.o. sp. k. Siedlce & Siedlce \\
\hline 6. & 1063 & Mostostal Siedlce sp. z o.o. sp. k. & Siedlce \\
\hline 7. & 1753 & Real S.A. & Siedlce \\
\hline 8. & 1756 & Grazmat sp. z o.o. sp. k. & Garwolin \\
\hline 9. & 1945 & Altrad Mostostal sp. z o.o. & Siedlce \\
\hline
\end{tabular}

Źródło: opracowanie MBPR na podstawie Listy 2000 Rzeczpospolitej (stan na 2019 r., edycja z 2020 r.) 


\section{Rozwój przedsiębiorczości w latach 2010-2019}

W 2019 r. najwięcej podmiotów gospodarczych w przeliczeniu na 1000 mieszkańców zarejestrowano w Łosicach (126) i Garwolinie (120). Nieco mniejsze wartości wskaźnika odnotowano w Węgrowie i Siedlcach (odpowiednio: 115 i 112), natomiast najmniejsze - w Sokołowie Podlaskim (106) (ryc. 4).

W latach 2010-2019 w każdym z analizowanych miast odnotowano wzrost wskaźnika, naprzemiennie z jego spadkiem. Największe średnioroczne tempo wzrostu liczby podmiotów gospodarczych na 1000 mieszkańców w analizowanym okresie zarejestrowano w Sokołowie Podlaskim i Łosicach (po 0,9\%), następnie w Węgrowie i Garwolinie (odpowiednio: $0,6 \%$ i $0,4 \%$ ). Najmniejszym tempem wzrostu wskaźnika rok do roku charakteryzowały się Siedlce $(0,1 \%)$.

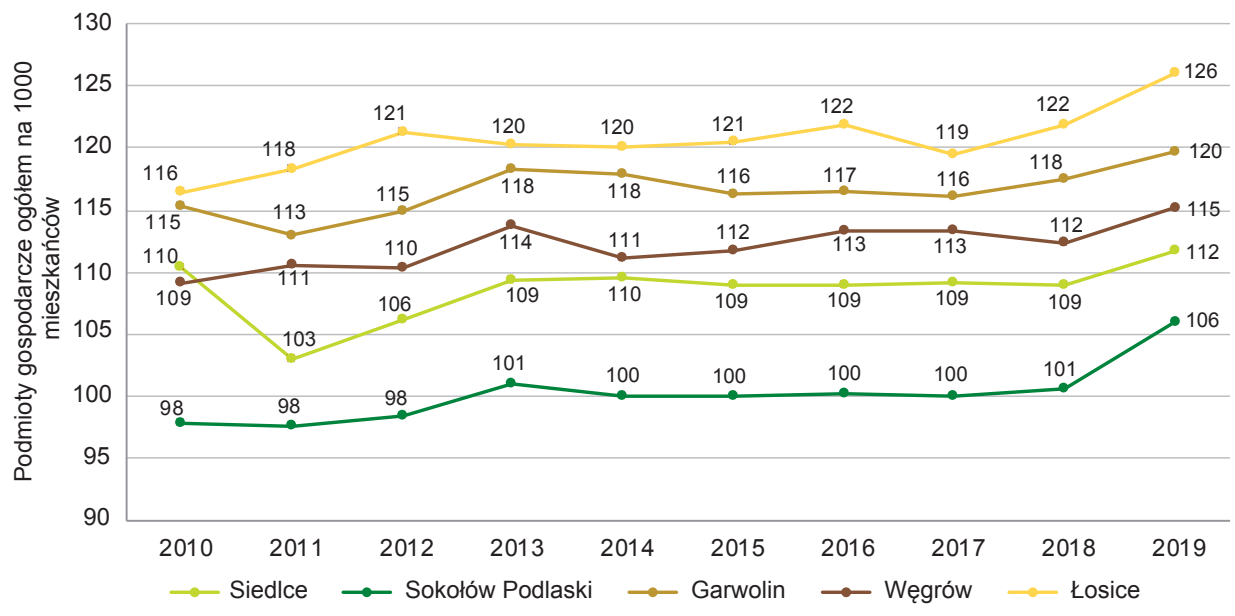

Ryc. 4. Podmioty gospodarcze ogółem na 1000 mieszkańców

Źródło: opracowanie MBPR na podstawie BDL

W każdym z analizowanych miast obserwuje się rokrocznie wyższą liczbę nowych przedsiębiorstw w stosunku do tych, które zostały wyrejestrowane (ryc. 5). W latach 20102019 najbardziej korzystną relację pomiędzy średnią liczbą nowo zarejestrowanych i wyrejestrowanych podmiotów gospodarczych odnotowano w Siedlcach, w których zarejestrowano średnio w okresie analiz o 105 więcej przedsiębiorstw niż średnio wyrejestrowano. W Sokołowie Podlaskim i Garwolinie przewaga nowo zarejestrowanych podmiotów gospodarczych nad wyrejestrowanymi wynosiła odpowiednio: 35 i 30. Najmniejsza przewagę średniej liczby nowo zarejestrowanych przedsiębiorstw w stosunku do wyrejestrowanych odnotowano w Węgrowie i Łosicach (odpowiednio o 22 i 15 przedsiębiorstw).

Kluczowym wskaźnikiem rozwoju przedsiębiorczości jest poziom bezrobocia [Rogala 2011]. Powstające podmioty gospodarcze kreuja nowe miejsca pracy, co prowadzi do 
zmniejszenia zjawiska bezrobocia. Wśród analizowanych miast największy udział zarejestrowanych bezrobotnych w liczbie osób w wieku produkcyjnym w 2019 r. odnotowano w Garwolinie (6,3\%) oraz w Sokołowie Podlaskim (5,1\%) (ryc. 6). Niższy poziom bezrobocia rejestrowanego odnotowano w Łosicach i Wegrowie (odpowiednio: 4,1\% i 4,0\%), natomiast najniższy - w Siedlcach $(3,2 \%)$.

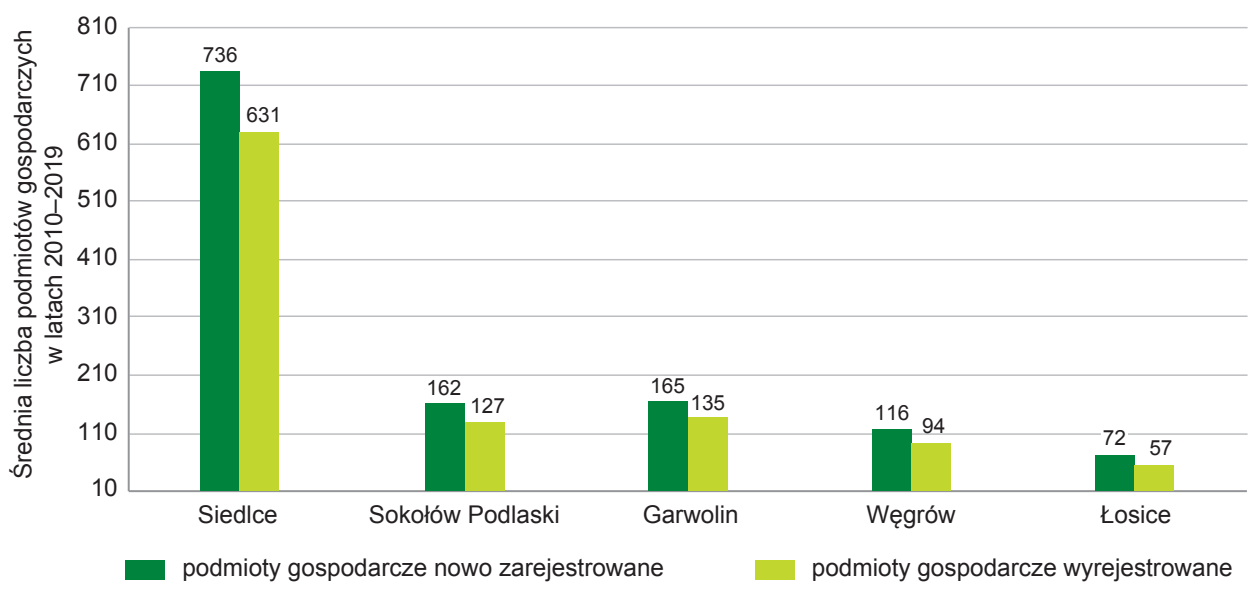

Ryc. 5. Średnia liczba nowo zarejestrowanych i wyrejestrowanych podmiotów gospodarczych ogółem w latach 2010-2019

Źródło: opracowanie MBPR na podstawie BDL

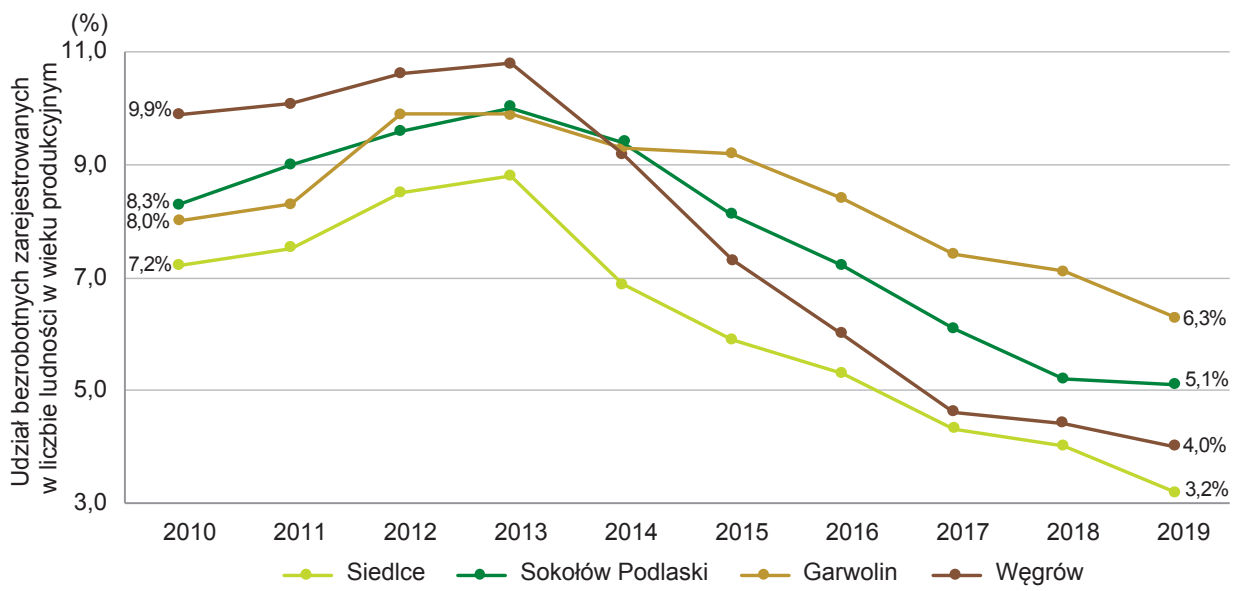

Ryc. 6. Udział bezrobotnych zarejestrowanych w liczbie ludności w wieku produkcyjnym Źródło: opracowanie MBPR na podstawie BDL 
W latach 2010-2019 udział bezrobotnych w liczbie ludności w wieku produkcyjnym zmniejszał się w miastach powiatowych subregionu siedleckiego, dla których dostępne były dane za cały analizowany okres ( $w$ związku z brakiem danych nt. powyższego wskaźnika przed 2019 r. dla Łosic, nie można stwierdzić zmian w tym zakresie dla tego miasta). Bezrobocie zmniejszało się najszybciej w Węgrowie (średniorocznie o 9,6\%) oraz w Siedlcach (o 8,6\%), natomiast najwolniej w Sokołowie Podlaskim i Garwolinie (odpowiednio o 5,3\% i 2,6\%).

Jednym z instrumentów wspierania przedsiębiorczości są wydatki inwestycyjne, ponoszone przez samorządy lokalne [Perska 2014].

W latach 2015-2019 najwyższe średnie wydatki inwestycyjne na 1 mieszkańca odnotowano w Siedlcach (845 zł) i Węgrowie (685 zł) (ryc. 7). Niższe wydatki w tym okresie odnotowano w Sokołowie Podlaskim i Garwolinie (odpowiednio: 493 i 473 zł na 1 mieszkańca). Z uwagi na brak danych dla Łosic, nie można określić poziomu i zmian ww. wskaźnika dla tego miasta. W latach 2015-2019 w porównaniu z analogicznym okresem 2010-2014 średnie wydatki inwestycyjne per capita wzrosły jedynie w Garwolinie (o 28,9\%), w pozostałych miastach odnotowano ich zmniejszenie. Największy spadek nastapił w Węgrowie (w latach 2015-2019 o 23\% mniejsze wydatki inwestycyjne w stosunku do lat 2010-2014), nieco mniejszy w Siedlcach i Sokołowie Podlaskim (odpowiednio o 8,2\% i 6,1\%).

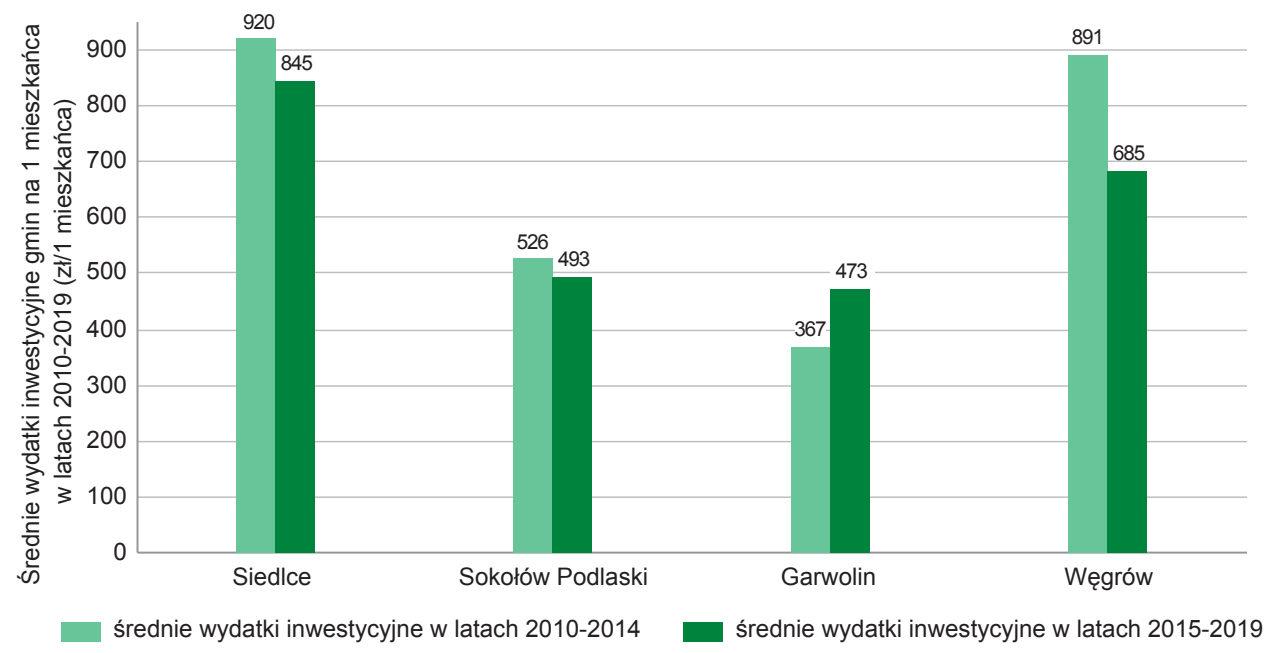

Ryc. 7. Średnie wydatki inwestycyjne samorządów lokalnych na 1 mieszkańca w latach 2010-2014 i 2015-2019

Źródło: opracowanie MBPR na podstawie BDL 


\section{Wykorzystanie środków publicznych na rozwój gospodarczy w latach 2010-2019}

Beneficjenci z miast powiatowych subregionu siedleckiego wykazują się dużym zaangażowaniem i skutecznością w pozyskiwaniu dofinansowania ze środków publicznych, w tym funduszy UE. W perspektywach finansowych obejmujących lata: 2007-2013 i 2014-2020, mogli oni aplikować o środki na rozwój gospodarczy z kolejnych edycji regionalnego programu operacyjnego województwa mazowieckiego i krajowych programów operacyjnych, m.in. w ramach obszarów interwencji: $B+R$ i Przedsiębiorczość, Społeczeństwo Informacyjne, Rozwój Zasobów Ludzkich. W ramach niniejszego artykułu wybrano do analizy ww. obszary wsparcia, mające największy wpływ na rozwój gospodarczy przedmiotowych miast.

Przedsiębiorcy i instytucje otoczenia biznesu skorzystali m.in. ze wsparcia w ramach Programu Operacyjnego Innowacyjna Gospodarka 2007-2013 (POIG 2007-2013) i Programu Operacyjnego Inteligentny Rozwój 2014-2020 (POIR 2014-2020), na realizację innowacyjnych projektów $\mathrm{B}+\mathrm{R}$, na rozbudowę i modernizację zakładów produkcyjnych i firm, a także na wdrażanie i stosowanie technologii informacyjnych i komunikacyjnych $\mathrm{w}$ przedsiębiorstwach. W latach 2010-2019 z powyższych programów krajowych w miastach powiatowych subregionu siedleckiego (z wyjątkiem Łosic, w których nie były zrealizowane inwestycje w przedmiotowych obszarach obydwu programów) zrealizowano łącznie 30 inwestycji z zakresu $B+R$ i Przedsiębiorczości oraz Społeczeństwa Informacyjnego. Większość z nich (90\%) powstało dzięki środkom unijnym z okresu programowania 2007-2013. Łączna wartość projektów zrealizowanych w obydwu perspektywach wynosiła 87,6 mln zł, z czego 39,9\% stanowiło dofinansowanie unijne. Najwięcej projektów - 14, o wartości 30,8 mln zł i dofinansowaniu 19,3 mln zł (tj. na poziomie 62,8\%) zrealizowano w Siedlcach. Zwraca również uwage 11 projektów zrealizowanych w Węgrowie, których wartość ogółem wynosiła 53,2 mln zł i była najwyższa w podregionie siedleckim (dofinansowanie unijne tych projektów wynosiło 26,1\%). Najwięcej środków unijnych na 1 mieszkańca w ramach POIG 2007-2013 i POIR 2014-2020 na projekty w ramach obszarów interwencji: $B+R$ i Przedsiębiorczość oraz Społeczeństwo Informacyjne (1,1 tys. zł) pozyskano w Węgrowie.

Projekty z zakresu Rozwoju zasobów ludzkich zrealizowane w ramach Programu Operacyjnego Kapitat Ludzki 2007-2013 (POKL)² i Programu Operacyjnego Wiedza Edukacja Rozwój 2014-2020 (POWER) uwzględnione w przedmiotowej analizie, dotyczyły poprawy jakości siły roboczej w przedsiębiorstwach oraz zwiększenia ich adaptacji do zmian, promocji przedsiębiorczości i innowacyjności, wsparcia samozatrudnienia i zakładania działalności gospodarczej, a także aktywizacji młodych bezrobotnych. W latach 2010-2019 w ramach tych programów zrealizowano 19 projektów, z czego aż 15 w okresie programowania 2014-2020. Łączna wartość projektów zrealizowana z obydwu programów wynosiła 47,1 mln zł, z czego $83,7 \%$ pochodziło z dofinansowania unijnego. W każdym z analizowanych miast zrealizo-

\footnotetext{
${ }^{2}$ W perspektywie finansowej 2007-2013 krajowy program POKL, z którego realizowane były m.in. projekty dotyczące rozwoju zasobów ludzkich, wdrażany był w części na poziomie regionów ( $w$ ramach tzw. komponentu regionalnego). W tekście opisano dofinansowanie unijne w ramach POKL (bez podziału na część krajową i komponent regionalny.
} 
wano podobną liczbę projektów: w Siedlcach, Sokołowie Podlaskim, Węgrowie i Łosicach po 4 projekty, natomiast w Garwolinie - 3. Największe projekty były zrealizowane w ramach POWER 2014-2020 przez Powiatowe Urzędy Pracy w Siedlcach i w Garwolinie - po 3 projekty o łącznej wartości ponad $12 \mathrm{mln}$ zł w każdym z ww. miast i dofinansowaniu ok. 84\% ze środków unijnych. Dotyczyły one m.in. organizacji szkoleń, staży i doradztwa zawodowego, a także dofinansowania założenia działalności gospodarczej dla osób młodych pozostających bez pracy). Najwyższą wartość dofinansowania na 1 mieszkańca zarejestrowano w Łosicach -726 zł, a najniższą w Siedlcach - 137 zł.

W miastach powiatowych subregionu siedleckiego, dzięki dwóm edycjom Regionalnego Programu Operacyjnego Województwa Mazowieckiego (RPO WM), zarządzanego przez Samorząd Województwa Mazowieckiego, w analizowanym okresie zrealizowano łącznie 87 projektów na rzecz rozwoju przedsiębiorczości. 69\% z nich powstało dzięki wsparciu unijnemu otrzymanemu w okresie finansowania 2007-2013. Łączna wartość projektów zrealizowanych w obydwu edycjach RPO WM wynosiła 189,4 mln zł, z czego 56\% stanowiło dofinansowanie unijne. Najwięcej projektów - 65 o wartości dofinansowania $83 \mathrm{mln}$ zł zrealizowano z zakresu $B+R$ i Przedsiębiorczość. Dotyczyły one m.in.: zakupu maszyn i urządzeń, wdrożenia innowacyjnych rozwiązań technologicznych, wprowadzania nowych produktów i usług, opracowania strategii rozwoju przedsiębiorstw, promocji firm na targach gospodarczych, a także przygotowania terenów pod działalność gospodarczą i wsparcia rozwoju ośrodków naukowych o wysokim potencjale badawczym. Najwięcej projektów w obydwu edycjach RPO WM zrealizowano w Siedlcach (38). Ich łączna wartość wynosiła 81,6 mln zł, a łączne dofinansowanie ze środków europejskich - 48,9\%. W pozostałych miastach liczba zrealizowanych projektów wynosiła od 9 (w Łosicach) do 15 (w Węgrowie). Trzy siedleckie projekty z ww. zakresu znalazły się na liście projektów kluczowych Regionalnego Programu Operacyjnego Województwa Mazowieckiego 2007-2013 (RPO WM 2007-2013), tj. projekt Collegium Mazovia Innowacyjnej Szkoły Wyższej w Siedlcach obejmujący budowę laboratorium metod profilaktycznych fizjoterapii (wartość dofinansowania: 1,3 mln zł), projekt Miasta Siedlce dotyczący kompleksowego przygotowania terenów pod działalność gospodarcza (wartość dofinansowania: 4,6 mln zł) oraz projekt UPH w Siedlcach dotyczący wzmocnienia potencjału badawczego uczelni (wartość dofinansowania: 0,5 mln zł). Ponadto w Sokołowie Podlaskim zrealizowano projekt dotyczący utworzenia Parku przemysłowego (wartość dofinansowania: 18,2 mln zł), a w Garwolinie - projekty obejmujące uzbrojenie terenów inwestycyjnych Garwolińskiej Strefy Aktywności Gospodarczej (łączna wartość dofinansowania: 17,9 mln zł). W obszarze interwencji Społeczeństwo Informacyjne przedsiębiorcy zrealizowali 6 projektów o wartości dofinansowania 0,9 mln zł, stanowiącej 33\% ich wartości całkowitej. Najwięcej projektów zrealizowano w Siedlcach (3), o łącznej wartości dofinansowania 0,7 mln zł, co stanowi ok 34\% ich wartości. W Sokołowie Podlaskim, Węgrowie i Garwolinie przedsiębiorcy zrealizowali po 1 projekcie w przedmiotowym obszarze interwencji, a wartość projektów w tych miastach wynosiła odpowiednio: 62,8 tys. zł, 125,7 tys. zł i 35 tys. zł. W ramach obszaru interwencji Rozwój zasobów ludzkich powstało 16 projektów (wartość dofinansowania $22 \mathrm{mln}$ zł) na rzecz poprawy umiejętności i kwalifikacji kadry pracowniczej, 
wspierania mobilności pracowników oraz aktywności zawodowej osób pozostających bez pracy. Najwięcej projektów - 6, zrealizowano w Siedlcach o łącznej wartości dofinansowania 7,7 mln zł, stanowiącej 80\% ich całkowitej wartości. Projekty zgłoszone przez Powiatowe Urzędy Pracy (PUP) w Siedlcach (2), Garwolinie (2) i Węgrowie (1), otrzymały najwyższe wsparcie unijnie - każdy po ponad 2 mln zł na szkolenia i kursy kwalifikacyjne dla bezrobotnych. W ramach dwóch edycji RPO WM dofinansowanie per capita w analizowanych miastach wahało się od 1529 zł w Sokołowie Podlaskim do 517 zł w Siedlcach.

W latach 2010-2019 wysokość środków unijnych, pozyskanych na wzmocnienie konkurencyjności przedsiębiorstw, była w analizowanych miastach bardzo zróżnicowana. Największe wsparcie unijne w ramach programów krajowych otrzymał Węgrów - 1689 zł na 1 mieszkańca (na realizację 15 projektów), a najniższe Sokołów Podlaski - 314 zł na 1 osobę (na 5 projektów) (ryc. 8). Najwyższe dofinansowanie per capita z RPO WM zarejestrowano w Sokołowie Podlaskim i Garwolinie (odpowiednio 1529 zł i 1425 zł), a najniższe odnotowano w Siedlcach (517 zł). Łącznie w ramach RPO WM i programów krajowych najwyższe wsparcie (powyżej 1500 zł na 1 osobę) otrzymali przedsiębiorcy z Węgrowa i Sokołowa Podlaskiego, a najwięcej projektów (56) zrealizowano w Siedlcach (tabela 2).

Tabela 2. Liczba zrealizowanych projektów i dofinansowanie unijne per capita w trzech obszarach interwencji: B+R i Przedsiębiorczość, Społeczeństwo Informacyjne i Rozwój Zasobów Ludzkich z programów krajowych i RPO WM w latach 2010-2019

\begin{tabular}{|c|c|c|c|c|c|c|}
\hline 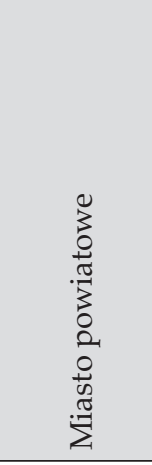 & 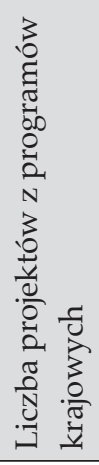 & $\begin{array}{l}\sum \\
3 \\
0 \\
0 \\
01 \\
N \\
3 \\
0 \\
0 \\
\frac{\pi}{0} \\
0 \\
0 \\
0 \\
0 \\
0 \\
0 \\
0 \\
0\end{array}$ & 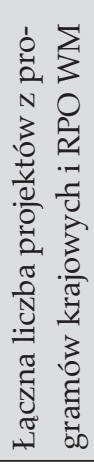 & 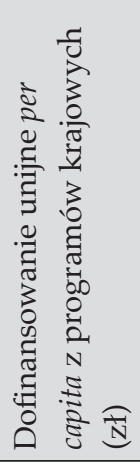 & 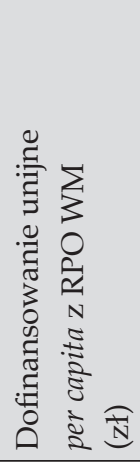 & 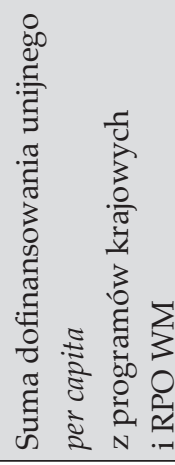 \\
\hline Siedlce & 18 & 38 & 56 & 388 & 517 & 905 \\
\hline $\begin{array}{l}\text { Sokołów } \\
\text { Podlaski }\end{array}$ & 5 & 13 & 18 & 314 & 1529 & 1843 \\
\hline Garwolin & 7 & 12 & 19 & 701 & 1425 & 2126 \\
\hline Węgrów & 15 & 15 & 30 & 1689 & 704 & 2393 \\
\hline Łosice & 4 & 9 & 13 & 726 & 585 & 1311 \\
\hline
\end{tabular}

Źródło: opracowanie MBPR na podstawie danych z serwisu internetowego Mapa Dotacji UE, Krajowego Systemu Informatycznego Monitoringu i Kontroli finansowej Funduszy Strukturalnych i Funduszu Spójności 2007-2013 (KSI SIMIK 2007-2013), Portalu Fundusze Europejskie i Mazowieckiej Jednostki Wdrażania Programów Unijnych 


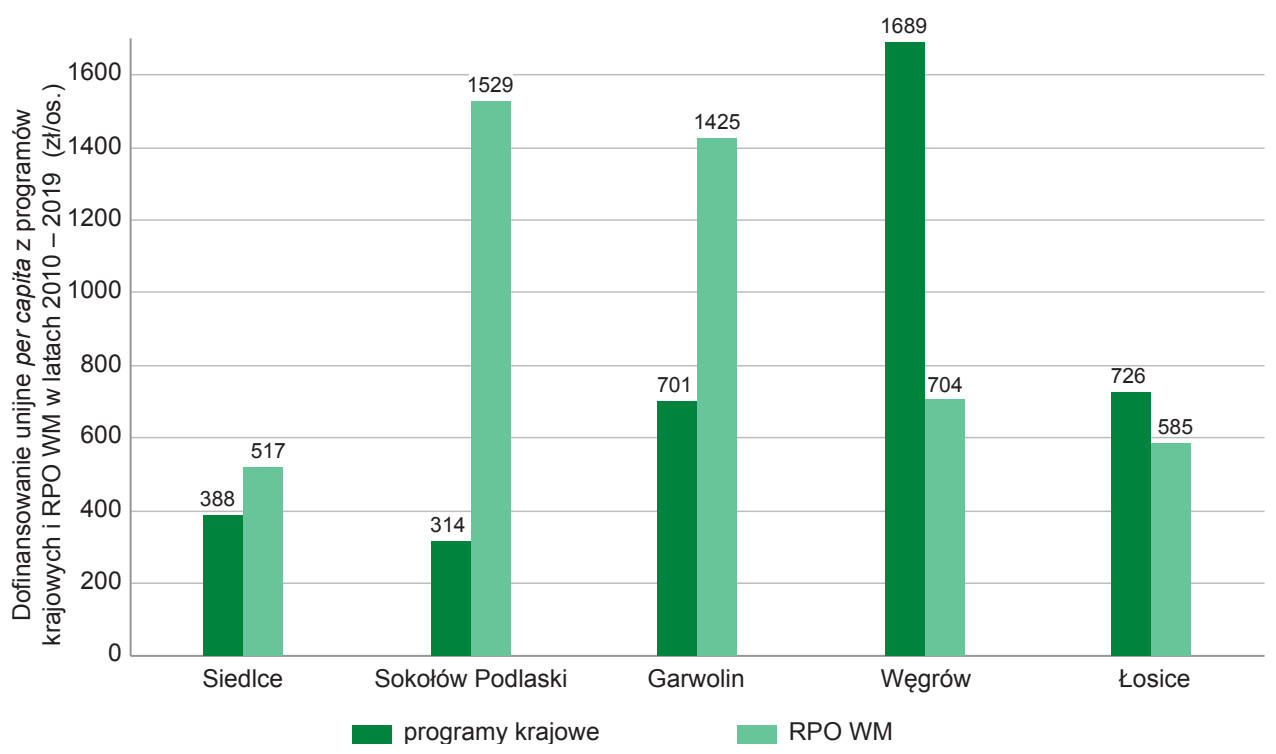

Ryc. 8. Dofinansowanie unijne per capita w trzech obszarach interwencji: B+R i Przedsiębiorczość, Społeczeństwo Informacyjne i Rozwój Zasobów Ludzkich z programów krajowych i z RPO WM w latach 2010-2019

Źródło: opracowanie MBPR na podstawie danych z serwisu internetowego Mapa Dotacji UE, KSI SIMIK 2007-2013, Portalu Fundusze Europejskie oraz Mazowieckiej Jednostki Wdrażania Programów Unijnych

\section{Podsumowanie}

Wyniki analiz przeprowadzonych na potrzeby niniejszego artykułu wskazuja, że wśród miast powiatowych subregionu siedleckiego najwyższym poziomem atrakcyjności gospodarczej charakteryzują się Siedlce, w których skoncentrowane są usługi wyższego rzędu, $\mathrm{w}$ tym organy administracji publicznej poziomu wojewódzkiego, oraz instytucje otoczenia biznesu. Miasto ma potencjał do przyciagania inwestorów, czego dowodem jest lokalizacja wielu dużych zakładów przemysłowych, m.in. z kapitałem zagranicznym. Położenie miasta w sieci komunikacyjnej, tj. w zasięgu korytarza o znaczeniu międzynarodowym, a także dobrze rozwinięta infrastruktura techniczna, stwarzają dogodne warunki do lokalizacji inwestycji. W mieście funkcjonują dwie duże dzielnice przemysłowe, w których część terenów objęta jest zasięgiem specjalnej strefy ekonomicznej.

W pozostałych ośrodkach powiatowych także zidentyfikowano korzystne uwarunkowania gospodarcze. Do najważniejszych atutów, świadczących o atrakcyjności inwestycyjnej tych miast, zalicza się: dobrą dostępność komunikacyjną, zwłaszcza Garwolina i Łosic, lokalizację uzbrojonych terenów inwestycyjnych, objętych częściowo strefami aktywności gospodarczej w: Węgrowie, Garwolinie i Sokołowie Podlaskim, a także aktywność władz lokalnych, np. w Łosicach, gdzie ustanowiono jeden z najniższych w kraju podatek od usług transportowych. 
Na przestrzeni kilkudziesięciu lat we wszystkich wymienionych miastach dobrze rozwinał się przemysł rolno-spożywczy, a ponadto wykształciły się dodatkowe specjalizacje gospodarcze. W Siedlcach rozwinał się przemysł metalowy i maszynowy, a w Garwolinie - przemysł chemiczny. W gospodarce Węgrowa ważną rolę pełni produkcja materiałów budowlanych, mebli i części do maszyn, a w Łosicach - działalność firm z zakresu transportu.

W latach 2010-2019 rozwój działalności gospodarczej w ośrodkach powiatowych subregionu siedleckiego charakteryzował się dużą zmiennością. We wszystkich miastach odnotowano średnioroczny przyrost podmiotów gospodarczych na 1000 mieszkańców, największy w Łosicach. W Siedlcach zwraca uwagę największa dynamika spadku bezrobocia - tę tendencję odnotowano również w każdym z przedmiotowych miast, dla których były dostępne dane statystyczne. Pozytywnym zjawiskiem w każdym z miast jest większa liczba nowo rejestrowanych podmiotów gospodarczych, niż liczba podmiotów wyrejestrowanych. Najbardziej korzystną relację w tym zakresie odnotowano w Siedlcach.

W analizowanym okresie samorzady lokalne miast powiatowych ponosiły znaczne wydatki inwestycyjne na rozwój, jednak były one znacznie większe w pierwszych 5 latach. W kolejnych latach (2015-2019) poziom tych wydatków w przeliczeniu na 1 mieszkańca w porównaniu z okresem 2010-2014 obniżył się we wszystkich miastach, z wyjątkiem Garwolina.

Znaczący wpływ na rozwój przedsiębiorczości w analizowanych miastach miało dofinansowanie ze środków publicznych, w tym środków UE. W latach 2010-2019 w ramach dwóch okresów programowania (2007-2013 i 2014-2020), największe dofinansowanie per capita z programów krajowych i wojewódzkich otrzymali beneficjenci z Węgrowa i Garwolina, natomiast najniższe z Siedlec, pomimo zrealizowania największej liczby projektów.

Przedmiotowa analiza wykazała, że miasta powiatowe subregionu siedleckiego charakteryzują się wysokim potencjałem do rozwoju gospodarczego, który odpowiednio wykorzystany przez władze lokalne i wzmocniony dalszym wsparciem finansowym, może przyczynić się do wzrostu konkurencyjności tych ośrodków.

\section{Słownik skrótów}

KSI SIMIK 2007-2013 - Krajowy System Informatyczny SIMIK 2007-2013 (System Informatyczny Monitoringu i Kontroli Finansowej Funduszy Strukturalnych i Funduszu Spójności 2007-2013)

BDL - Bank Danych Lokalnych Głównego Urzędu Statystycznego

PKD 2007 - Polska Klasyfikacja Działalności określona w Rozporządzeniu Rady Ministrów z dnia 24.12.2007 r. w sprawie Polskiej Klasyfikacji Działalności (PKD)

POIG 2007-2013 - Program Operacyjny Innowacyjna Gospodarka 2007-2013

POKL 2007-2013 - Program Operacyjny Kapitał Ludzki 2007-2013 
POIR 2014-2020 - Program Operacyjny Inteligentny Rozwój 2014-2020

POWER 2014-2020 - Program Operacyjny Wiedza Edukacja Rozwój 2014-2020

PUP - Powiatowy Urząd Pracy

RPO WM - Regionalny Program Operacyjny Województwa Mazowieckiego w perspektywach finansowych: 2007-2013 i 2014-2020

UE - Unia Europejska

\section{Literatura}

Baron M., Bartoszek A., Blazy R., Gasidło K,. Janiszek M., Klasik A., Markowski T., MazurBelzyt K., Palmen L., Pancewicz A., Pięta-Kanurska M., Runge J., Twardoch A., Wrana K., 2019, Budowanie atrakcyjności przestrzeni miejskich, Studia KPZK, 194, Komitet Przestrzennego Zagospodarowania Kraju, PAN, Warszawa.

Brambert P., 2011, Ocena potencjału przedsiębiorczości i atrakcyjności gospodarczej obszarów wiejskich województwa świętokrzyskiego [w:] W. Kamińska (red.), Ocena potencjału przedsiębiorczości i atrakcyjności gospodarczej obszarów wiejskich województwa świętokrzyskiego, Instytut Geografii Uniwersytetu Jana Kochanowskiego, Kielce, s.149-162.

Chojnicki Z., Czyż T., 2004, Główne aspekty regionalnego rozwoju społeczno-gospodarczego [w:] J.J. Parysek (red.), Rozwój regionalny i lokalny w Polsce w latach 1989-2002, Bogucki Wydawnictwo Naukowe, Poznań, s. 13-24.

Dej M. (red.), 2016, Rozwój gospodarczy. Raport o stanie polskich miast 2016, Wydawnictwo Naukowe Instytutu Rozwoju Miast i Regionów, Kraków.

Lista 2000 Rzeczpospolitej (stan na 2019 r., edycja z 2020 r.)

Musiał-Malago M., 2017, Ocena potencjatu przedsiębiorczości i atrakcyjności gospodarczej obszaru funkcjonalnego Krakowa, Studia KPZK, 174, Komitet Przestrzennego Zagospodarowania Kraju, PAN, Warszawa.

Perska A., 2014, Wydatki inwestycyjne jednostek samorzadu terytorialnego jako instrument wspierania przedsiębiorczości, Przedsiębiorczość - Edukacja, 10, 285-294.

https: / / doi.org/10.24917/ 20833296.10 .21

Rogala K., 2011, Uwarunkowania przedsiębiorczości w obszarze mikroprzedsiębiorstw na przykładzie miasta Leszno. Niepublikowana praca doktorska, Uniwersytet Ekonomiczny, Poznań.

Starzyńska W., 2006, Podstawy statystyki: podręcznik: praca zbiorowa, Difin, Warszawa. 


\section{Dokumenty i akty prawne}

Gminny program rewitalizacji miasta Sokołów Podlaski na lata 2016-2026, uchwała nr XXII/122/ 2017 Rady miejskiej w Sokołowie Podlaskim z dnia 3 lutego 2017.

Plan zagospodarowania przestrzennego województwa mazowieckiego, uchwała nr 22/18 Sejmiku Województwa Mazowieckiego z dnia 19 grudnia 2018 r.

Rozporządzenie Rady Ministrów z dnia 24 grudnia 2007 r. w sprawie Polskiej Klasyfikacji Działalności (Dz.U. z 2007 r., poz. 1885).

Strategia rozwoju miasta Garwolina na lata 2016-2023, uchwała nrXXVI/171/ 2016 Rady Miasta Garwolina z dnia 31 sierpnia 2016.

Strategia rozwoju miasta i gminy Łosice do 2020 roku, uchwała nr XVI/113/15 Rady Miasta i Gminy Łosice z dnia 29 grudnia 2015 r.

Strategia rozwoju miasta Siedlce do 2025 roku, uchwała nr XIV / 157/2015 Rady Miasta Siedlce $\mathrm{z}$ dnia 27 listopada $2015 \mathrm{r}$.

Strategia rozwoju miasta Sokołów Podlaski do 2017 roku, uchwała Nr XLVI/274/ 2002 Rady Miejskiej w Sokołowie Podlaskim z dnia 10 października 2002 r.

Strategia rozwoju miasta Wegrowa do 2020 roku, uchwała nr VIII/34/2015 Rady Miejskiej Węgrowa z dnia 29 maja 2015 r.

Studium uwarunkowań i kierunków zagospodarowania przestrzennego miasta Garwolina, uchwała nr LIX/333 / 2018 Rady Miasta Garwolina z dnia 24 maja 2018 r.

Studium uwarunkowań i kierunków zagospodarowania przestrzennego miasta Siedlce, uchwała nr XXXVI/ 658/ 2013 Rady Miasta Siedlce z dnia 29 listopada 2013 r.

Studium uwarunkowań i kierunków zagospodarowania przestrzennego miasta Sokołów Podlaski, uchwała nr XIV / 68 / 99 Rady Miejskiej w Sokołowie Podlaskim z dnia 29 lipca 1999 r.

Ustawa z dnia 10 maja 2018 r. o wspieraniu nowych inwestycji (Dz.U. z 2020 r., poz. 1752).

\section{Strony internetowe}

https: / / bdl.stat.gov.pl [dostęp: 15.03.2021]

https: / / garwolin.pl [dostęp: 15.03.2021]

https: / / gminalosice.pl / pl [dostęp: 15.03.2021]

https: / / www.google.pl/maps [dostęp: 15.04.2021]

https: / / mapadotacji.gov.pl [dostęp: 15.04.2021] 
https: / / www.paih.gov.pl / 20120521 / garwolinska_strefa_aktywnosci_gospodarczej [dostęp: 10.08.2021]

https:/ / rankingi.rp.pl/lista2000/2020/lista_2000 [dostęp: 15.04.2021]

http: / / www.simik.24xls.com [dostęp: 4.03.2019]

https:/ / sokolowpodl.pl [dostęp: 15.03.2021]

https:/ / www.wegrow.com.pl [dostęp: 15.03.2021]

\section{Selected aspects of economic attractiveness and entrepreneurship development of county towns in the Siedlce subregion in the years 2010-2019}

\section{ABSTRACT}

The article analyzes selected elements of the economic attractiveness of county towns in the Siedlce subregion (NUTS 3 Siedlce statistical subregion), located in the eastern part of the Mazovian Voivodeship. As part of the analysis, the most important conditions of the economic development of these county towns were characterized, taking into account transport connections and designated investment areas, as well as the most important aspects of economic activity in these towns, including the largest enterprises and major economic specializations. Selected development processes in the field of entrepreneurship were analyzed, as well as the amount of EU funds obtained by the beneficiaries from these towns aimed at improving the competitiveness of enterprises. The analysis covers the period from 2010 to 2019.

Key words: Siedlce subregion, county towns, economic attractiveness, entrepreneurship development, UE grants

\footnotetext{
Agata Kucharska - absolwentka gospodarki przestrzennej Uniwersytetu Warszawskiego, pracownik samorzqdowy, kontakt: Mazowieckie Biuro Planowania Regionalnego w Warszawie, Oddział Terenowy w Siedlcach ul. Pułaskiego 19/21, 08-110 Siedlce, e-mail:akucharska@mbpr.pl.

Agata Kucharska - graduate of the University of Warsaw in the field of spatial management; regional government employee, contact: Mazovian Office for Regional Planning in Warsaw, Branch Office in Siedlce, ul. Pułaskiego 19/21, 08-110 Siedlce, e-mail: akucharska@mbpr.pl.
}

Dariusz Piwowarczyk - absolwent gospodarki przestrzennej Uniwersytetu Warmińsko-Mazurskiego w Olsztynie, studia podyplomowe w zakresie rewitalizacji architektoniczno-urbanistycznej obszarów miejskich na Politechnice Gdańskiej, pracownik samorzqdowy, kontakt: Mazowieckie Biuro Planowania Regionalnego w Warszawie, Oddział Terenowy w Siedlcach, ul. Pułaskiego 19/21, 08110 Siedlce, e-mail:dpiwowaczyk@mbpr.pl.

Dariusz Piwowarczyk - graduate of the University of Warmia and Mazury in Olsztyn in the field of spatial management, postgraduate of the Gdańsk University of Technology in the field of architectural and urban revitalization of urban areas, regional government employee, contact: Mazovian Office for Regional Planning in Warsaw, Branch Office in Siedlce, ul. Pułaskiego 19/21, 08-110 Siedlce, e-mail:dpiwowowarczyk@mbpr.pl. 